\title{
Scaled-chrysophyte assemblage changes in the sediment records of lakes recovering from marked acidification and metal contamination near Wawa, Ontario, Canada
}

\author{
Christine M. GREENAWAY, ${ }^{1}$ Andrew M. PATERSON,${ }^{2 *}$ Wendel (Bill) KELLER, ${ }^{3}$ John P. SMOL ${ }^{1}$ \\ ${ }^{1}$ Queen's University, Paleoecological Environmental Assessment and Research Laboratory, Department of Biology, Kingston, \\ Ontario, K7L 3N6, Canada; ${ }^{2}$ Ontario Ministry of the Environment, Dorset Environmental Science Centre, 1026 Bellwood Acres \\ Road, P.O. Box 39, Dorset, Ontario, P0A 1E0, Canada; ${ }^{3}$ Laurentian University, Cooperative Freshwater Ecology Unit, Sudbury, \\ Ontario, P3E 2C6, Canada \\ *Corresponding author: andrew.paterson@ontario.ca
}

\begin{abstract}
A remarkable example of point-source lake acidification and metal pollution, and subsequent recovery in water quality, has occurred in lakes near the former iron sintering plant at Wawa (Ontario, Canada). Surface water pH levels in some of these lakes have increased from three to seven following local sulphur emission reductions and eventual closure of the sintering plant. Previous paleolimnological work documented striking successional changes in diatom species assemblages within dated sediment cores that could be related to past industrial activities. To gain additional insights into the chemical and biological recovery trajectories of the Wawa lakes, we used paleolimnological techniques to track euplanktonic scaled-chrysophyte (classes Chrysophyceae and Synurophyceae) species assemblage responses to historical water quality changes in five lakes. Coincident with the period of iron sintering from 1939 to 1998 , striking successional changes were noted in the sedimentary profiles, with marked increases in the relative abundances of the acid-and metal-tolerant taxon Synura echinulata. The scaled chrysophyte changes pre-dated diatom responses, confirming the former's status as reliable early warning indicators of lake acidification. Following closure of the sintering plant, species-specific chrysophyte responses to decreased emissions varied amongst the study lakes, perhaps reflecting differences in local bedrock geology and hydrological regime. Although some water chemistry variables may have recovered to near pre-industrial levels, similar to the diatom study, our data show that chrysophyte assemblages in the most recent sediments are now significantly different from pre-industrial assemblages.
\end{abstract}

Key words: Paleolimnology, chrysophytes, acidification, lakes, mining.

Received: January 2012. Accepted: May 2012.

\section{INTRODUCTION}

Sintering of low-grade siderite commenced in 1939 at a plant two kilometers northwest of Wawa (Ontario, Canada). Sulphur dioxide emissions increased steadily from 1939 to 1973, when they peaked at $>250,000$ tonnes per year (Rowe, 1999). By the 1950s, a teardrop-shaped fume-kill area had developed northeast of the sinter plant in the direction of predominant winds (Gordon and Gorham, 1963). Despite the presence of carbonate-bearing bedrock within some lake catchments, the acid neutralizing capacity of some lakes was exceeded. Acidified lakes reached extremely low $\mathrm{pH}$ values of less than four, while surrounding lakes remained near neutral (Gordon and Gorham, 1963; Rao and LeBlanc, 1967; Somers and Harvey, 1984).

Following a reduction of emissions since 1973, and final closure of the iron sintering plant in 1998, several lakes near Wawa showed signs of rapid chemical and biological recovery from acidification and metal-contamination (2003-2005, D.A. Jackson, University of Toronto,
Ontario, unpublished data). Striking increases in $\mathrm{pH}$ and alkalinity, as well as decreases in $\mathrm{SO}_{4}, \mathrm{Al}, \mathrm{Fe}$ and $\mathrm{Mn}$ concentrations, indicate that major changes in water chemistry have occurred since the late 1970s (Greenaway et al., 2012). These lakes provide a unique opportunity for studying biological recovery patterns in an area with a naturally-occurring high buffering capacity. They also provide an interesting comparison with the striking changes occurring in softwater lakes near Sudbury (Ontario), following marked declines in point-source deposition from the local copper and nickel smelting activities (Gunn, 1995).

Previous paleolimnological research showed that stratigraphically-preserved diatom microfossils in the sediment records of five lakes in the fume-kill area near Wawa have responded to both marked acidification and to chemical improvements in some lakes (Greenaway et al., 2012). However, the timing and rate of diatom species' recovery was not synchronous among lakes, and was likely influenced by local bedrock geology and the hydrological regime of each lake (e.g. flushing rate). Furthermore, diatom commu- 
nities did not appear to be progressing towards their predisturbance assemblages, possibly due to high metal concentrations in surface sediments.

Scaled-chrysophytes (classes Chrysophyceae and Synurophyceae) comprise an alternate biological indicator group that is also commonly used in paleolimnological studies (Smol, 1995). Because they are exclusively planktonic, scaled-chrysophytes may provide novel insights into changes occurring in the pelagic zone of the Wawa fume-kill lakes. The siliceous nature of chrysophyte scales enables them to be well-preserved in lake sediment (Smol, 1995). These structures are often ornamented and easy to identify to species (Smol, 1988). Scaled-chrysophytes are highly abundant and ubiquitous across many ecosystems (Smol, 1980). Because they have narrow niche breadths, short life cycles, and fast migrations rates, living communities are sensitive and respond rapidly to changing environmental conditions.

Sensitivities to changing lake water $\mathrm{pH}$ have been documented for many scaled-chrysophyte species, which make them an excellent indicator group for use in acidification and recovery studies (Paterson et al., 2001; Smol, 1995). Predictive techniques and an improved understanding of ecological preferences allow for quantitative and qualitative inferences of historical $\mathrm{pH}$ based on scaledchrysophytes in the sediment record (e.g. Cumming et al., 1992a; S.S. Dixit et al., 1999, 2002; Paterson et al., 2002). These have been used to demonstrate regional acidification due to industrial $\mathrm{SO}_{2}$ emissions (Charles, 1990; Cumming et al., 1992b; A.S. Dixit et al., 1992a,b; S.S. Dixit et al., 1992), as well as recovery trajectories following emission reductions (A.S. Dixit et al., 1992a,b; S.S. Dixit et al., 1989a; Smol et al., 1998). Many species have also been identified as metal-tolerant or metal-sensitive (S.S. Dixit et al., 1989b), making them useful indicators of general trends in metal contamination and recovery.

There are several advantages to combining diatoms and scaled-chrysophytes in paleoecological studies of acidification and recovery. Most importantly, there may be differences in the timing of diatom and scaled-chrysophyte species compositional change in the sediment record. For example, chrysophyte-inferred $\mathrm{pH}$ changes commonly predate diatom-inferred changes in acidification studies (Hartmann and Steinberg, 1986; A.S. Dixit et al., 1992a,b; Smol and Dixit, 1990). Furthermore, several studies have shown that the magnitude of acidification is much greater when inferred from chrysophytes than from diatoms, likely because of their planktonic nature, and because many chrysophyte taxa dominate the phytoplankton assemblage during the critical spring melt period (Cumming et al., 1992b; S.S. Dixit et al., 2002; Gibson et al., 1987). The combined use of diatoms and chrysophytes provides a more complete understanding of $\mathrm{pH}$ history than would be generated from using either group alone (e.g. Paterson et al., 2001).
In this paper, we use paleolimnological techniques to track scaled-chrysophyte assemblage responses to historical chemical changes in five lakes near Wawa that have been previously studied for diatom assemblage changes (Greenaway et al., 2012). We show marked increases in acid- and metal-tolerant chrysophyte species in the 1950s and 1960s, pre-dating diatom responses to acidification. Following closure of the iron sintering plant in 1973, we present evidence of biological recovery from acidification, although the recovery trajectory varies among the study lakes, both in terms of timing and in the chrysophtye species present.

\section{Study sites}

Wawa is located in the northern Algoma district, northeast of Lake Superior, in the province of Ontario (Fig. 1). The study area straddles part of the Michipicoten greenstone belt, a complex Archean metavolcanic-metasedimentary assemblage recognized for its numerous banded iron formations containing massive siderite beds (Sage, 1994). The carbonate beds are composed dominantly of siderite and contain varying amounts of sulphides in the form of pyrite (Sage, 1993). Lakes northeast of Wawa that are associated with these carbonate beds exhibit higher natural $\mathrm{pH}$ levels than are typical of lakes along the eastern shore of Lake Superior (Coker and Shilts, 1979).

Gordon and Gorham (1963) described five zones of terrestrial damage ranging from Very severe to Not obvious. The limits of the Severe zone (which included the Very severe zone, and most of which experienced extensive soil erosion resulting in a barren rock landscape) and the Moderate zone (beyond which terrestrial effects were not obvious) are outlined in Fig. 1. Many lakes within the Severe zone reached $\mathrm{pH}$ levels below four and obtained high metal concentrations at some point in the 1950 s to 1970s (Somers and Harvey, 1984).

Sulphur dioxide emissions decreased from 1973 to 1998 when the sinter plant ceased production (Rowe, 1999). Recolonization by grasses, herbs and young white birch was already underway by 1998 (Ontario Ministry of the Environment, 1999). In 2006, the landscape was covered with sparsely populated white birch, reaching heights of 20 feet. No formal lake restoration efforts were put in place; however, remarkable natural chemical and biological recovery has recently been documented (Greenaway et al., 2012; D.A. Jackson, University of Toronto, Ontario, 2003-2005, unpublished data).

Five lakes that had previously been documented as being acidic and metal-contaminated (Somers, 1980) were chosen for scaled-chrysophyte analyses. These are: Little Soulier, Otter, Talbot, Lagarde and Blueberry lakes. Physical and chemical characteristics of the study lakes can be found in Tables 1 and 2. 


\section{METHODS}

Field work took place between June 6 and 9, 2006. Sediment cores were taken near the deepest point of each lake basin, using a depth sounder and the available bathymetric maps (from Somers, 1980) as a guide. In some lakes, a secondary basin was chosen for coring because of its enhanced accessibility (Otter lake), or to avoid an area with visible shoreline erosion along a steep bank (Talbot lake).

Sediment cores were extracted using a Glew (1989) gravity corer with $7.6 \mathrm{~cm}$ diameter Lexan ${ }^{\mathbb{B}}$ tubes that were $50 \mathrm{~cm}$ in length. A minimum core length of $22 \mathrm{~cm}$ was obtained from all lakes except Talbot lake, for which the longest obtainable core was $18 \mathrm{~cm}$. On shore, a Glew (1988) vertical extruder was used to section each core into $0.25 \mathrm{~cm}$ intervals for the top $10 \mathrm{~cm}$ and $0.5 \mathrm{~cm}$ thereafter. Sediment intervals were stored in individual Whirlpak ${ }^{\circledR}$ sample bags and transported in coolers for processing at the Paleoecological Environmental Assessment and Research Laboratory, Queen's University, Kingston, Ontario.

Radiometric dates were calculated to establish continuous age/depth relationships in sediment cores from all five lakes. Selected sediment intervals were dried using a Virtus $^{\circledR}$ freeze-dryer and prepared for analysis following procedures outlined in Schelske et al. (1994). Gamma emissions from each sample were measured by spectrometry using an EG\&G Ortec ${ }^{\circledR}$ germanium detector. Gross counts from regions of interest within the energy spectrum were used to calculate the activities of ${ }^{137} \mathrm{Cs}$, total ${ }^{210} \mathrm{~Pb}$ and ${ }^{214} \mathrm{Bi}$ (measured as an estimate of ${ }^{226} \mathrm{Ra}$-supported ${ }^{210} \mathrm{~Pb}$ ), as outlined in Schelske et al. (1994). ${ }^{210} \mathrm{~Pb}$ dates and sediment accumulation rates were calculated using the constant rate of supply (CRS) model (Appleby and Oldfield, 1978) and CRS computer program developed by Binford (1990). Dates were extrapolated for the last three $\mathrm{cm}$ of each core assuming a constant accumulation rate prior to human disturbance.

Preparation of slides for scaled-chrysophyte and diatom analyses (Greenaway et al., 2012) followed standard laboratory procedures as outlined in Battarbee et al. (2001). Sediment sub-samples were first treated with hydrochloric acid to remove carbonates and iron precipitates and then with a strong nitric-sulphuric acid mixture to remove the remaining organic material. Both treatments were followed by rinsing with de-ionized water until a neutral $\mathrm{pH}$ was achieved. The residual siliceous slurry was mounted on glass slides with Naphrax ${ }^{\circledR}$.

Chrysophyte scales were enumerated at $1000 \mathrm{x}$ magnification using a LEICA DMR2 light microscope with differential interference contrast and an oil immersion objective (numerical aperture $=1.3$ ). Scales were identified

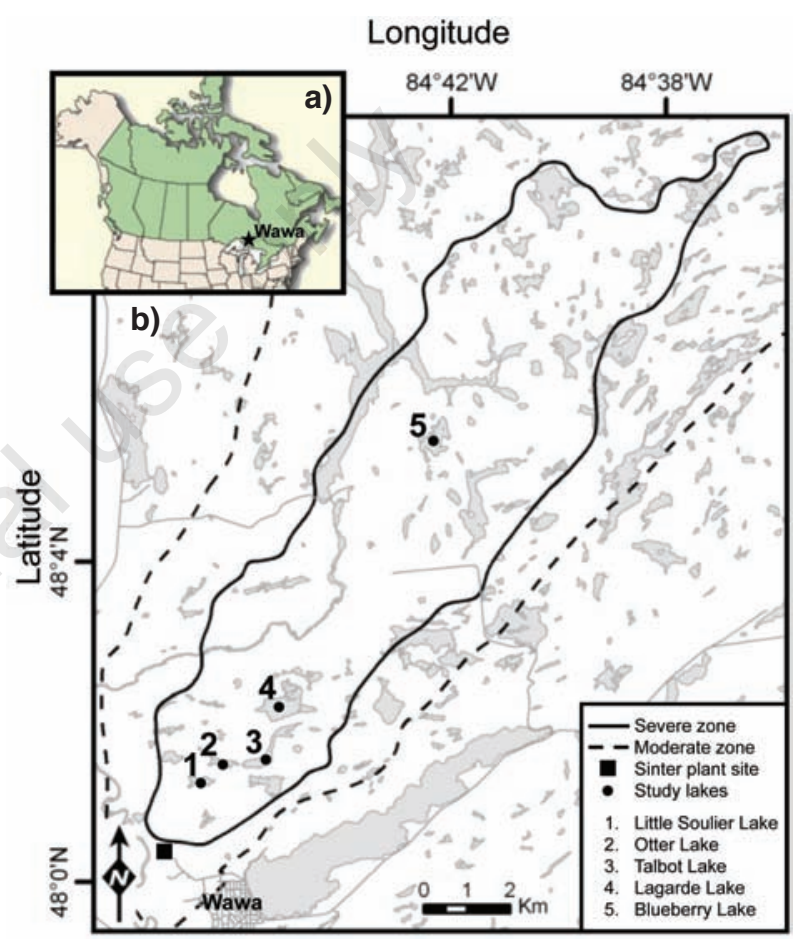

Fig. 1. a) Map of Canada and the general location of the Wawa fume-kill area; b) Location of the fume-kill lakes (solid circles), as well as approximate limits of the Severe (dotted line) and Moderate (solid line) zones of terrestrial damage described by Gordon and Gorham (1963). Following the onset of iron sintering, much of the Severe zone was characterized by soil erosion and barren rock (Gordon and Gorham, 1963). Beyond the Moderate zone, no obvious terrestrial effects were observed.

Tab. 1. Location and physical characteristics of the fume-kill lakes selected for this study.

\begin{tabular}{|c|c|c|c|c|c|c|c|c|}
\hline & $\begin{array}{l}\text { Latitude }(\mathrm{N}) \text { and } \\
\text { longitude }(\mathrm{W})\end{array}$ & $\begin{array}{c}\text { Distance from } \\
\text { sinter plant }(\mathrm{km})\end{array}$ & $\begin{array}{c}\text { Zone of terrestrial } \\
\text { damage }^{*}\end{array}$ & $\begin{array}{l}\text { Watershed } \\
\text { area }^{\#}\left(\mathrm{~km}^{2}\right)\end{array}$ & $\begin{array}{c}\text { Lake surface } \\
\operatorname{area}^{\S}\left(\mathrm{km}^{2}\right)\end{array}$ & $\begin{array}{l}\text { Lake volume } \\
\qquad\left(\mathrm{m}^{3}\right)\end{array}$ & $\begin{array}{l}\text { Maximum } \\
\operatorname{depth}^{\S}(\mathrm{m})\end{array}$ & $\begin{array}{c}\text { Flushing } \\
\text { time }^{\#} \text { (years) }\end{array}$ \\
\hline Little Soulier lake & $48^{\circ} 01^{\prime} 12^{\prime \prime}, 84^{\circ} 46^{\prime} 53^{\prime \prime}$ & $1.8 \mathrm{NE}$ & Very severe & 6.01 & 0.084 & $31.4 \times 10^{4}$ & 19.2 & $\sim 0.1$ \\
\hline Otter lake & $48^{\circ} 01^{\prime} 24^{\prime \prime}, 84^{\circ} 46^{\prime} 27^{\prime \prime}$ & $2.3 \mathrm{NE}$ & Very severe & 5.44 & 0.064 & $39.5 \times 10^{4}$ & 17.4 & $\sim 0.2$ \\
\hline Talbot lake & $48^{\circ} 01^{\prime} 25^{\prime \prime}, 84^{\circ} 45^{\prime} 53^{\prime \prime}$ & $3.1 \mathrm{NE}$ & Severe & 3.47 & 0.240 & $275.8 \times 10^{4}$ & 24.5 & $\sim 1.7$ \\
\hline Lagarde lake & $48^{\circ} 02^{\prime} 05^{\prime \prime}, 84^{\circ} 45^{\prime} 35^{\prime \prime}$ & $4.1 \mathrm{NE}$ & Very severe & 1.25 & 0.532 & $779.4 \times 10^{4}$ & 46.1 & $\sim 10.3$ \\
\hline Blueberry lake & $48^{\circ} 05^{\prime} 21^{\prime \prime}, 84^{\circ} 42^{\prime} 32^{\prime \prime}$ & $11.2 \mathrm{NE}$ & Severe & 1.06 & 0.321 & $152.4 \times 10^{4}$ & 18.5 & $\sim 2.6$ \\
\hline
\end{tabular}

${ }^{*}$ Defined by Gordon and Gorham (1963); " calculations made from visual estimates of watershed limit on topographic maps; ${ }^{\xi}$ measured or calculated by Somers (1980). 
to the lowest possible taxonomic level using standard chrysophyte flora descriptions (Asmund and Kristiansen, 1986; Siver, 1991; Takahashi, 1978; Kling and Kristiansen, 1983; Nicholls, 1982; Nicholls and Gerrath, 1985). A number of small or medium-sized, unidentifiable Mallomonas species were combined into the groups Mallomonas small or Mallomonas medium (sensu Paterson et al., 2001). We appreciate that these groupings may combine several diverse taxa, but in all cases the population sizes of these categories were small and so did not affect our overall interpretations. The ratio of the percent abundance of chrysophyte scales to diatom frustules was also calculated. In the sediment core from Little Soulier lake, intervals were selected to match the high-resolution sampling pattern used for diatom analysis (Greenaway et al., 2012). In the four other study lakes, intervals were selected at a much coarser resolution, with the purpose of providing a preliminary assessment of general changes through time.

Prior to the species data analyses, raw scaled-chrysophyte species counts were standardized to relative abundance within each interval. As marked in the figures, some sediment intervals were counted to a low sample size (i.e. $<50$ scales) because chrysophyte scales occurred at very low density relative to diatom frustules. The relative abundance of species in samples with counts of 50 scales or fewer should be interpreted with caution because it is not possible to verify that the relative abundance of each species was stable between incremental counts. Within each core, only those species that were present in at least four intervals and present at relative abundances of more than $1 \%$ in at least two of the intervals were included in the numerical analyses. One interval was removed altogether from the analysis $(10 \mathrm{~cm}$ interval in Blueberry lake), because the scales showed significant clumping on the microscope slide, preventing a proper assessment of species' abundances.
To explore scaled-chrysophyte assemblage shifts through time, the species assemblage from each sediment interval was compared to the average pre-industrial species assemblage using the Bray-Curtis dissimilarity coefficient (Clarke and Warwick, 1994). The average pre-industrial assemblage was calculated from all intervals that were ${ }^{210} \mathrm{~Pb}$-dated as earlier than $\sim 1939$, the year when sintering commenced at the sinter plant near Wawa.

\section{RESULTS AND DISCUSSION}

Species compositions of scaled-chrysophytes recorded in the sediment of the study lakes changed markedly in the second half of the $20^{\text {th }}$ century (Figs. 2 to 6). Although responses were variable between lakes, most changes corresponded with the documented period of acidification in the Very severe zone (Gordon and Gorham, 1963; Somers and Harvey, 1984). Interestingly, the ratio of chrysophyte scales to diatom frustules also changed markedly throughout the lake sediment records, with the lowest ratios observed during the period of intense acidification.

Nine chrysophyte species were observed at high enough relative abundances (i.e. greater than one percent in at least two intervals) to warrant further discussion. As this is the first such study from the Wawa region, discussion of ecological optima of the various taxa will be based on calibration studies from other regions, with an emphasis on comparable studies from Sudbury, Ontario, due to its proximity to Wawa and similar industrial history (i.e. metals mining).

\section{Pre-disturbance species assemblages}

In all lake sediment cores, the pre-industrial scaledchrysophyte species assemblages were dominated by Mallomonas duerrschmidtiae and/or Mallomonas pseu-

Tab. 2. Lake water chemistry data measured in 1978-79 and in 2006 in the fume-kill lakes selected for this study.

\begin{tabular}{|c|c|c|c|c|c|c|c|c|c|c|}
\hline & \multicolumn{2}{|c|}{ Little Soulier lake } & \multicolumn{2}{|c|}{ Otter lake } & \multicolumn{2}{|c|}{ Talbot lake } & \multicolumn{2}{|c|}{ Lagarde lake } & \multicolumn{2}{|c|}{ Blueberry lake } \\
\hline & $1978^{*}$ & $2006^{\#}$ & $1978^{*}$ & $2006^{\#}$ & $1979^{*}$ & $2006^{\#}$ & $1979^{*}$ & $2006^{\#}$ & $1979^{*}$ & $2006^{\#}$ \\
\hline Alkalinity $\left(\mathrm{CaCO}_{3} \mathrm{mg} \mathrm{L}^{-1}\right)$ & 0.00 & 19.40 & 0.00 & 14.90 & 0.00 & 15.30 & 0.00 & 5.06 & 0.00 & 8.94 \\
\hline $\mathrm{pH}$ & 3.16 & 6.97 & 3.09 & 7.14 & 3.30 & 7.37 & 4.05 & 6.52 & 3.78 & 7.01 \\
\hline Specific conductivity $\left(\mu \mathrm{S} \mathrm{cm}^{-1}\right)$ & 819.3 & 98.4 & 904.0 & 88.4 & na & 95.2 & 216.0 & 84.0 & 102.1 & 50.2 \\
\hline Secchi depth (m) & 6.5 & 6.3 & 7.3 & 5.3 & na & 8.2 & 15.0 & 7.5 & 3.0 & 3.5 \\
\hline Sulphate $\left(\mathrm{mg} \mathrm{L}^{-1}\right)$ & 242.00 & 23.60 & 55.00 & 22.00 & 187.00 & 25.00 & 96.00 & 28.80 & 56.00 & 11.80 \\
\hline Calcium $\left(\mathrm{mg} \mathrm{L}^{-1}\right)$ & 33.00 & 15.00 & 43.60 & 13.20 & 32.40 & 13.10 & 20.50 & 12.40 & 13.80 & 7.44 \\
\hline Magnesium (mg L-1) & 21.20 & 3.12 & 30.30 & 2.82 & 18.40 & 3.29 & 5.18 & 2.12 & 1.58 & 0.71 \\
\hline Chloride $\left(\mathrm{mg} \mathrm{L}^{-1}\right)$ & 1.40 & 0.20 & 1.50 & 0.20 & 1.05 & 0.18 & 0.55 & 0.31 & 0.30 & 0.18 \\
\hline Potassium (mg L $\left.{ }^{-1}\right)$ & 1.00 & 0.23 & 1.20 & 0.18 & 0.78 & 0.19 & 0.56 & 0.22 & 0.51 & 0.26 \\
\hline Aluminum ( $\left.\mu \mathrm{g} \mathrm{L}^{-1}\right)$ & 3090 & 4.86 & 5430 & 6.26 & 3680 & 16.80 & 2280 & 4.86 & 290 & 7.38 \\
\hline Copper $\left(\mu \mathrm{g} \mathrm{L}^{-1}\right)$ & 26 & 0.40 & 33 & 0.38 & 18 & 0.64 & 12 & 0.31 & 0 & 1.04 \\
\hline Iron $\left(\mu \mathrm{g} \mathrm{L}^{-1}\right)$ & $4^{\S}$ & 78.40 & 9040 & 134.00 & 4420 & 26.50 & 966 & 16.20 & 364 & 34.20 \\
\hline Manganese $\left(\mu \mathrm{g} \mathrm{L}^{-1}\right)$ & 4332 & 19.50 & 6381 & 18.90 & 3710 & 19.30 & 2420 & 39.60 & 482 & 8.59 \\
\hline
\end{tabular}

${ }^{*}$ From Somers (1980) and Somers and Harvey (1984); " from Greenaway (2009) and Greenaway et al. (2012); sin a 1979 resample of Little Soulier lake, Fe was measured to be $2080 \mu \mathrm{g} L^{-1}$ (Somers, 1980); na, not available. 
docoronata, and were characterized by minimal species compositional change (Figs. 2 to 6). The taxon $M$. duerrschmidtiae was originally described from acidic lakes low in specific conductivity and total phosphorus in the United States (Siver et al., 1990). The pH optimum (5.8) calculated from 105 lakes in Sudbury (S.S. Dixit et al., 2002) is comparable to that calculated from 146 lakes in the northeastern USA (pH optimum 6.2; S.S. Dixit et al., 1999), where it was described as being most abundant in moderate to low $\mathrm{pH}$ waters. It has also dominated pre-disturbance species assemblages in many Sudbury lakes (Uutala et al., 1994; A.S. Dixit et al., 1996; S.S. Dixit et al., 2002) and has been referred to as a generalist in other studies (Uutala et al., 1994). Meanwhile, M. pseudocoronata is commonly found in circumneutral to alkaline waters (Cumming et al., 1992a; S.S. Dixit et al., 1999, 2002) and in Sudbury has a pH optimum of 6.7 (S.S. Dixit et al., 2002). The co-dominance of M. pseudocoronata implies that these lakes were probably circumneutral prior to the onset of sintering. This is substantiated by the low, but stable, down-core abundance of $M$. caudata in most cores, which is commonly restricted to circumneutral lakes ( $\mathrm{pH}$ optimum 6.5 in Sudbury; S.S. Dixit et al., 2002).

\section{Responses to acidification and metal contamination}

The nature of species compositional changes following the onset of sintering (1939) varied among lakes. In all lake sediment cores, the appearance or increase in the relative abundance of new species was contemporaneous with a decrease in the relative abundances of $M$. duerrschmidtiae and M. pseudocoronata. The most consistent response was an increase in the relative abundance of Synura echinulata in each lake's sediment core (Figs. 2 to 6 ). The peak relative abundance of this species ranged from 15 to $50 \%$, and it did not always become the most abundant species in the assemblage; however, the similarity of its response to that in Sudbury lakes ( $\mathrm{pH}$ optimum 5.8; S.S. Dixit et al., 2002) is worth noting. S. echinulata has frequently been observed to be abundant in acidic and metal-contaminated lakes in Sudbury (S.S. Dixit et al., 1989a,b, 2002; A.S. Dixit et al., 1992b), despite being described as bimodal along the $\mathrm{pH}$ gradient from lakes in the Adirondack Mountains and in south-central Ontario (Cumming et al., 1992a; Paterson et al., 2001), and considered to be tolerant of a wide $\mathrm{pH}$ range in the northeastern USA (S.S. Dixit et al., 1999).

Increases in the relative abundances of Mallomonas crassisquama and $M$. hamata in some of the Wawa lakes during the period of acidification were inconsistent with trends observed for these species in other regions. $M$. crassisquama, with a $\mathrm{pH}$ optimum of 6.6 in Sudbury lakes (S.S. Dixit et al., 1999; Siver et al., 1990), is commonly found in circumneutral lakes, and rarely identified in sediments from very acidic lakes. This taxon has also been reported as aluminum-sensitive in the Adirondack Mountains (Cumming et al., 1992a), and potentially cop-

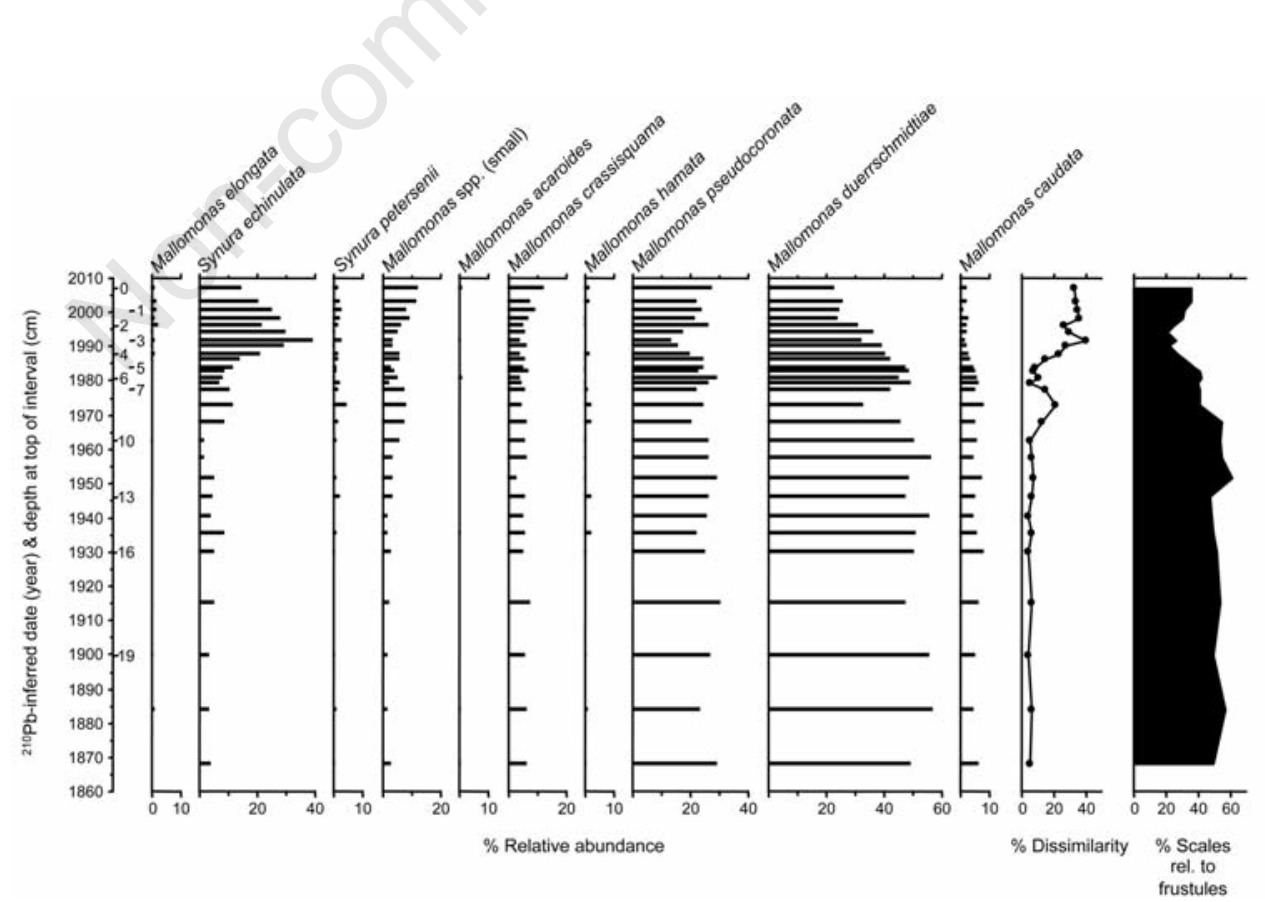

Fig. 2. Little Soulier lake sediment core scaled to ${ }^{210} \mathrm{~Pb}$-inferred dates, showing: i) the relative abundance of common scaled-chrysophyte taxa; ii) the Bray-Curtis dissimilarity between each scaled-chrysophyte species assemblage and the average pre-industrial (pre-1939) assemblage; and iii) the percent of chrysophyte scales relative to diatom frustules. 


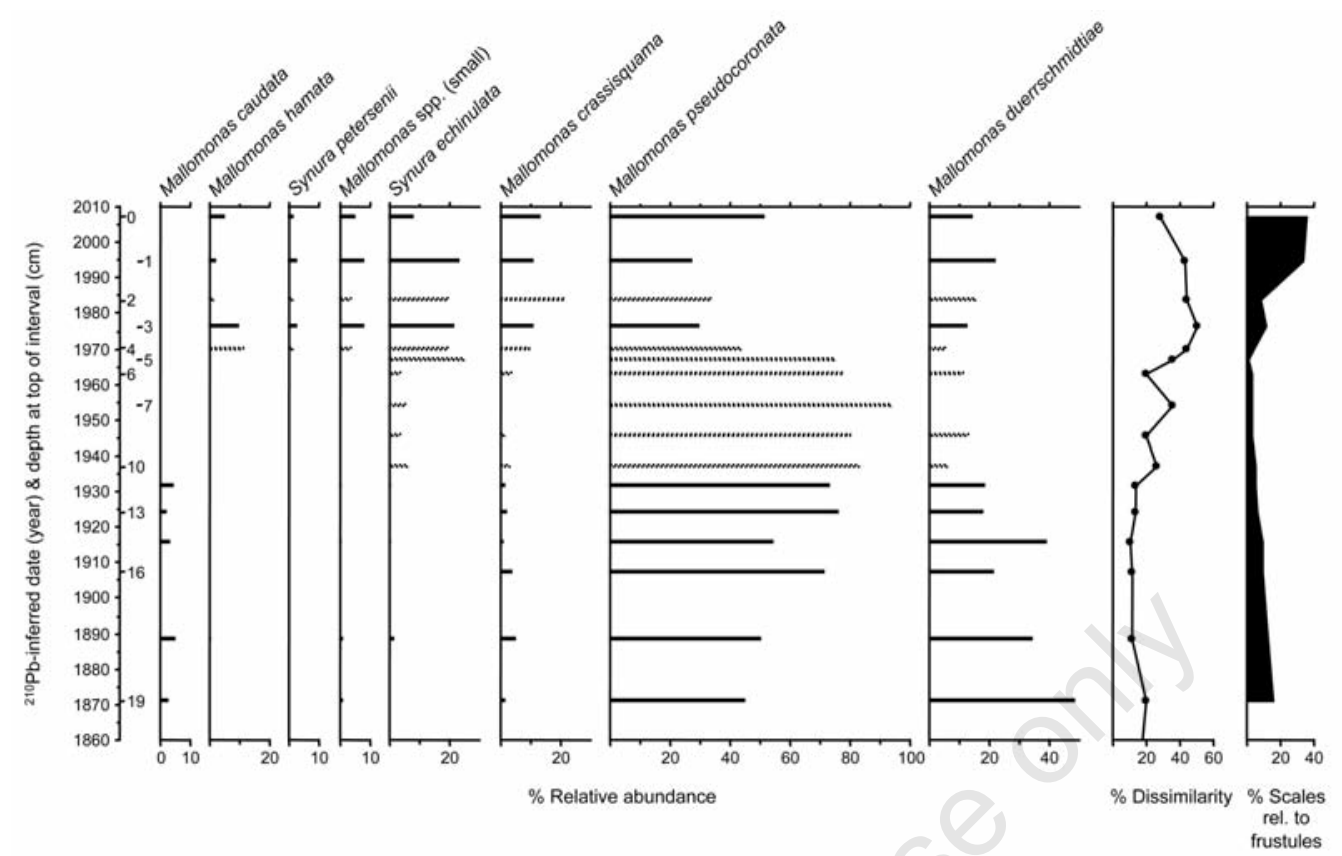

Fig. 3. Otter lake sediment core scaled to ${ }^{210} \mathrm{~Pb}$-inferred dates, showing: i) the relative abundance of common scaled-chrysophyte taxa; ii) the Bray-Curtis dissimilarity between each scaled-chrysophyte species assemblage and the average pre-industrial (pre-1939) assemblage; and iii) the percent of chrysophyte scales relative to diatom frustules. Dashed bars indicate intervals for which sample sizes were $\leq 50$, due to the low concentration of scales.

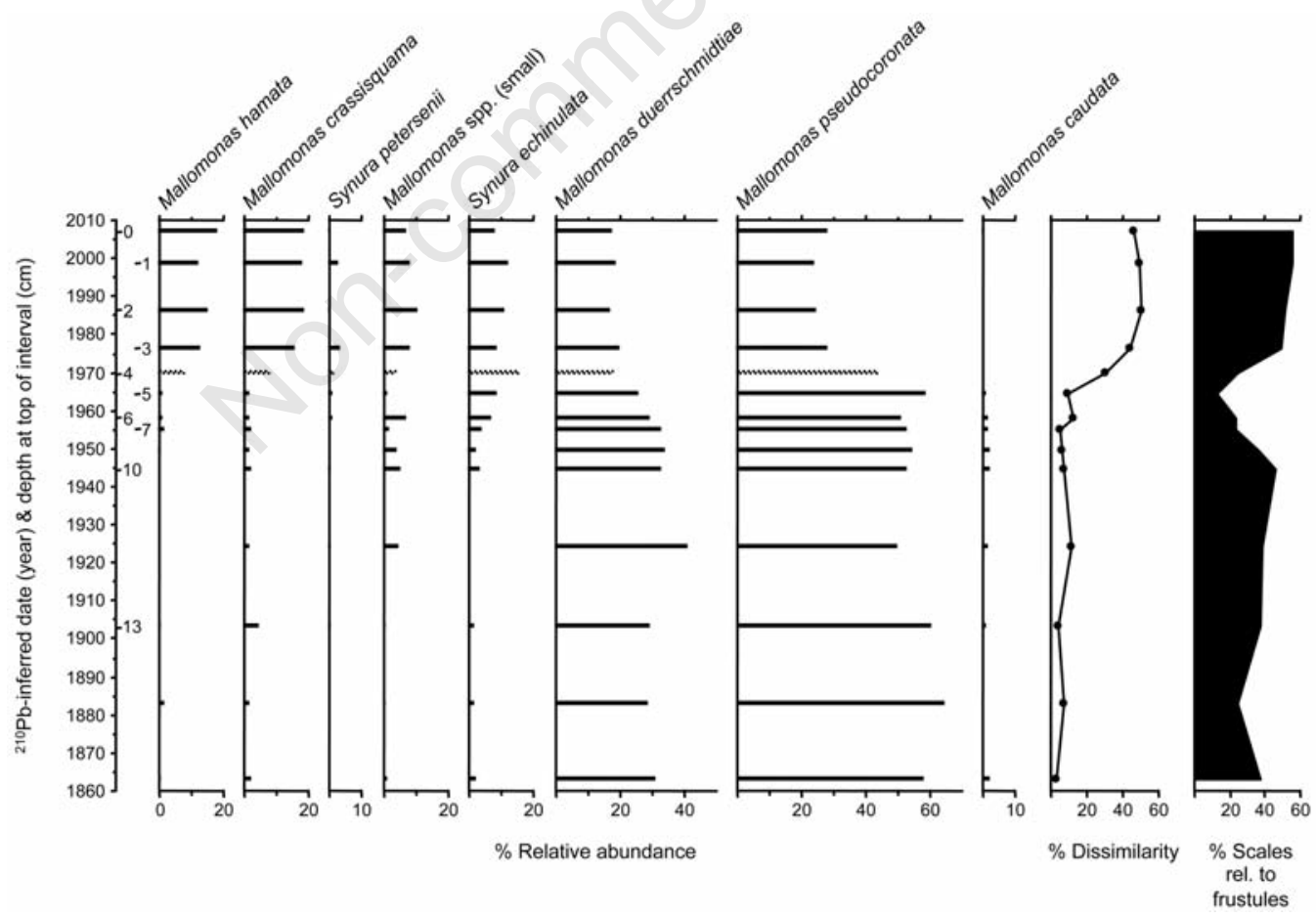

Fig. 4. Talbot lake sediment core scaled to ${ }^{210} \mathrm{~Pb}$-inferred dates, showing: i) the relative abundance of common scaled-chrysophyte taxa; ii) the Bray-Curtis dissimilarity between each scaled-chrysophyte species assemblage and the average pre-industrial (pre-1939) assemblage; and iii) the percent of chrysophyte scales relative to diatom frustules. Dashed bars indicate intervals for which sample sizes were $\leq 50$, due to the low concentration of scales. 


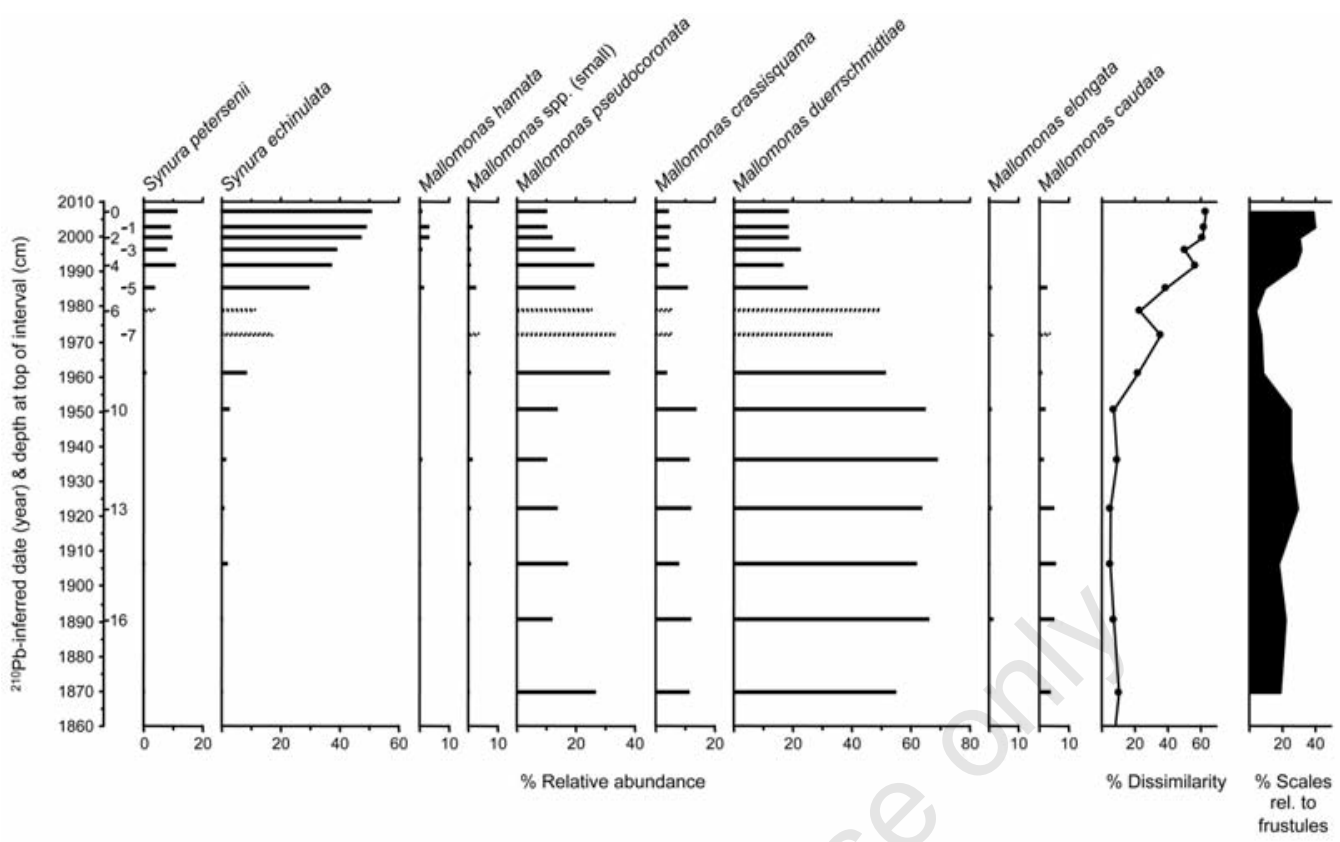

Fig. 5. Lagarde lake sediment core scaled to ${ }^{210} \mathrm{~Pb}$-inferred dates, showing: i) the relative abundance of common scaled-chrysophyte taxa; ii) the Bray-Curtis dissimilarity between each scaled-chrysophyte species assemblage and the average pre-industrial (pre-1939) assemblage; and iii) the percent of chrysophyte scales relative to diatom frustules. Dashed bars indicate intervals for which sample sizes were $\leq 50$, due to the low concentration of scales.

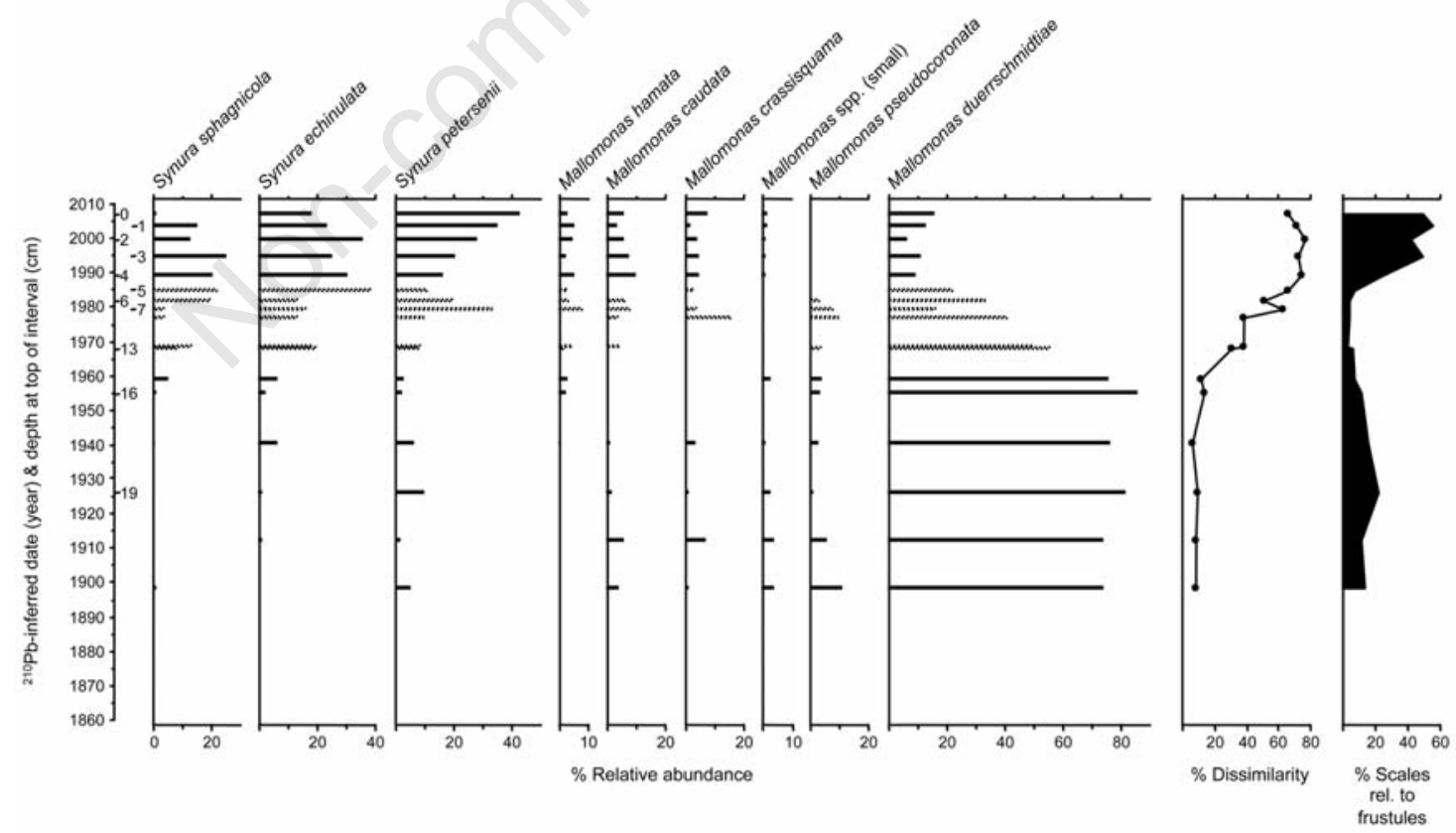

Fig. 6. Blueberry lake sediment core scaled to ${ }^{210} \mathrm{~Pb}$-inferred dates, showing: i) the relative abundance of common scaled-chrysophyte taxa; ii) the Bray-Curtis dissimilarity between each scaled-chrysophyte species assemblage and the average pre-industrial (pre-1939) assemblage; and iii) the percent of chrysophyte scales relative to diatom frustules. Dashed bars indicate intervals for which sample sizes were $\leq 50$, due to the low concentration of scales. 
per- and nickel-sensitive in Sudbury (S.S. Dixit et al., 1989b). M. hamata was observed to be a common taxon of acidic lakes in the Adirondacks (Cumming et al., 1992a), but was less common in Sudbury lakes (pH optimum in Sudbury 5.9; S.S. Dixit et al., 2002), again due to copper- and nickel-sensitivity (S.S. Dixit et al., 1989b, 1992, 2002). However, these taxa were present and increased to sub-dominance in some of the Wawa lake sediment cores following the onset of sintering. In the late 1970s, copper and nickel concentrations were higher in the four fume-kill lakes closest to the sinter plant $(\mathrm{Cu} 12-$ $26 \mu \mathrm{g} \mathrm{L}^{-1}$; Ni 5-33 $\mu \mathrm{g} \mathrm{L}^{-1}$; Somers, 1980), relative to background concentrations from surrounding lakes $(\mathrm{Cu}$ 0-2 $\mu \mathrm{g} \mathrm{L}^{-1}$; Ni $0 \mu \mathrm{g} \mathrm{L}{ }^{-1}$; Somers, 1980), although not comparable to the extremely high concentrations of some Sudbury lakes (S.S. Dixit et al., 1989b). Aluminum concentrations were much more elevated in the fume-kill lakes (2260 $\mu \mathrm{g} \mathrm{L}^{-1}$ - $5430 \mu \mathrm{g} \mathrm{L}{ }^{-1}$; Somers, 1980; Somers and Harvey, 1984). Clearly, the factors affecting acidand metal-sensitivity are complex and likely elementspecific, which may explain why variation in species responses is prevalent across regions.

One additional species, S. petersenii, also became more abundant in each lake sediment core after sintering commenced. This increase was relatively small in Little Soulier, Otter and Talbot lakes (Figs. 2 to 4), but greater $(5-10 \%)$ in Lagarde and Blueberry lakes (Figs. 5 and 6). S. petersenii has been described as $\mathrm{pH}$-indifferent in Sudbury (S.S. Dixit et al., 2002) and was most abundant around $\mathrm{pH} 7.0$ across the northeastern USA (S.S. Dixit et $a l ., 1999)$. Its abundance has recently increased in many Ontario lakes (S.S. Dixit et al., 2002; Paterson et al., 2001, 2004), although not directly with changes in lake $\mathrm{pH}$. Meanwhile, S. sphagnicola (Sudbury pH optimum 6.2; S.S. Dixit et al., 2002) increased to high abundance only in Blueberry lake. Increases in the abundance of Synura scales in sediment cores in lakes across Ontario may reflect the influence of acidification, climate change, or both (Hyatt et al., 2010; Paterson et al., 2004, 2008; Schindler et al., 1996). For example, although the specific mechanisms for their rise have not yet been determined, colonial chrysophytes may realize a competitive advantage under conditions of increased light penetration and associated altered thermal regimes (Paterson et al., 2004; Hyatt et al., 2010). A recent work in New Hampshire lakes (Davis et al., 2006) has also reported increases in colonial chrysophytes that are coeval with increases in coal combustion products and major and trace metals in lake sediments. Iron, in particular, has been shown to be a limiting nutrient for some freshwater algae, and the higher abundances of some chrysophyte taxa in highly coloured lakes has been related to readily available, chelated forms of iron and other trace metals in such lakes (Sandgren, 1988).

\section{Differential response of scaled-chrysophytes and diatoms}

In all five lakes, clear indications of species compositional change occurred in sediment dated from approximately the late 1950s and throughout the 1960s. This coincides with the time period when Gordon and Gorham (1963) measured very low $\mathrm{pH}$ in small lakes and ponds in the Very severe zone. In Little Soulier, Otter and Talbot lakes, early signs of change in benthic diatom species compositions were recorded around the same period; however, the major diatom species compositional changes in all five lakes occurred at varying times throughout the next few decades (Greenaway et al., 2012). Thus, scaledchrysophyte species appear to have responded earlier than diatoms to lake acidification in the Wawa fume-kill area. This was particularly notable in Lagarde lake, in which diatom species' responses (as recorded in the sediment) were delayed until $\sim 1990$, but chrysophyte species responses in the sediment commenced in the late 1950s.

A lag in response of diatoms relative to scaled-chrysophytes has been observed in other lakes (Hartmann and Steinberg, 1986; A.S. Dixit et al., 1992a,b; Cumming et al., 1994), and may be related to differences in habitat. Lake sediments are an important source of alkalinity in many lakes (Carignan, 1985; Schiff and Anderson, 1986; Schindler et al., 1986), and the majority of the acid- and metal-indicator diatom species in these lakes were benthic forms (Greenaway et al., 2012). The pre-disturbance benthic diatom communities in the Wawa fume-kill area lakes likely experienced a microhabitat that was well-buffered relative to the overlying water column, thus allowing them to persist for some time after the onset of surface water acidification.

The period of rapid transition in species composition, and the period of intense acidification ( 1950-1970), were also characterized by very low abundances of chrysophyte scales relative to diatom frustules (Figs. 2 to 6). In some cases (e.g. Talbot lake), the decrease in the ratio of chrysophyte scales to diatom frustules appeared to precede the onset of chrysophyte species compositional change, suggesting that this measure may be useful as an early warning indicator of lake acidification. Furthermore, scaled-chrysophytes appear to be show an enhanced sensitivity to chemical changes occurring within the water column, compared to diatom assemblages, because of their planktonic nature.

\section{Responses to chemical improvements in water column}

The study lakes have exhibited striking chemical improvements since the late 1970s, including an increase in $\mathrm{pH}$ and alkalinity and a decrease in metal concentrations in the water column (Greenaway et al., 2012; D.A. Jackson, University of Toronto, Ontario, 2003-2005, unpub- 
lished data). Similar to diatom community responses (Greenaway et al., 2012), the responses of scaled-chrysophyte communities varied among lakes (Fig. 7). Broadly, the lakes can be divided into three general groups, with some overlap, based on the chrysophyte response to chemical improvements.

The first group, including Little Soulier, Otter and Blueberry lakes, show qualitative evidence for biological recovery. In these lake sediment cores, the relative abundance of $S$. echinulata began to decrease in intervals dated from approximately the 1990s (Figs. 2, 3 and 6). A decrease in this acid- and metal-tolerant taxon (A.S. Dixit et al., 1992a,b; S.S. Dixit et al., 1989b, 2002) is most likely a reflection of the improving water quality conditions in these lakes, and was most obvious in the high-resolution sediment core analysis from the Little Soulier lake (Fig. 2). Interestingly, the decrease in S. echinulata at the top of the Blueberry lake core contrasts sharply with the diatom analysis, in which virtually no response to water quality improvements was observed (Greenaway et al., 2012). At least for Blueberry lake, this again suggests a lagged response of the diatom community to chemical changes in water quality, although this time in response to chemical recovery. The more rapid response of scaledchrysophytes to improvements in chemical water quality may be due to their planktonic nature and rapid species turnover rates. Scaled-chrysophytes appear to be reliable early-warning indicators of both acidification and chemical recovery in some lakes.

In contrast, the scaled-chrysophyte record in the Talbot lake sediment core appears to have stabilized in the 1970s, showing virtually no evidence for reversal in the acidification trend (Fig. 4), although a very small decrease in S. echinulata in the top sediment interval may be an early indication of recovery. In the Talbot lake diatom record (Greenaway et al., 2012), evidence for recovery was also limited to the top interval of the core. However, diatom evidence constituted a decrease in several taxa and therefore was considered to be more substantial than the decrease seen here. Despite measured water chemistry improvements following closure of the sinter plant in 1998, it can be inferred from the lack of strong evidence for recovery in either the chrysophyte or diatom sediment record that chemical improvements were likely to have

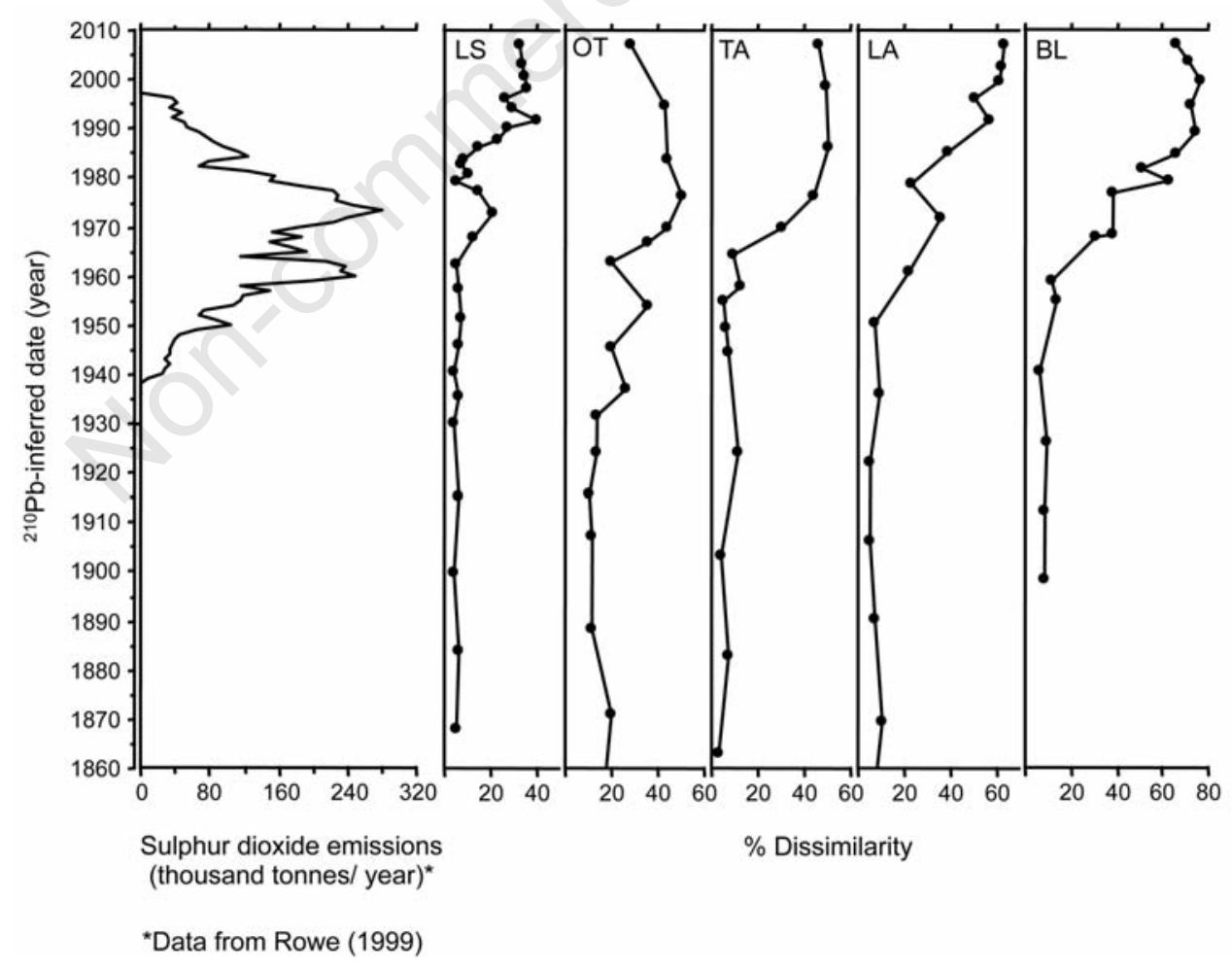

Fig. 7. A comparison of the Bray-Curtis dissimilarity trends through time in Little Soulier (LS), Otter (OT), Talbot (TA), Lagarde (LA), and Blueberry (BL) lakes. The Bray-Curtis dissimilarity was calculated between each scaled-chrysophyte species assemblage and the average pre-industrial (pre-1939) assemblage from that lake. Historical sulphur dioxide emissions from the sinter plant are also shown (data from Rowe, 1999). 
been recent. Talbot lake is a small, but relatively deep lake with an estimated flushing time of $\sim 1.7$ years (Greenaway, 2009). It is the first major lake within the Talbot Creek watershed. In contrast, Little Soulier and Otter lakes are small, shallow, secondary and tertiary lakes of the Talbot Creek watershed, with much shorter flushing times, as well as higher ratios of catchment and sediment to lake volume. These varied hydrological regimes may explain why Talbot lake appears to have lagged behind Little Soulier and Otter lakes in timing of chemical recovery, and in evidence for diatom and chrysophyte recovery from the sediment record (Fig. 7).

A final group of lakes was characterized by a shift to Synura-dominated assemblages within the most recent intervals of the lake sediment cores. In Lagarde and Blueberry lakes, the recovery trajectories are unlikely to include a return to pre-disturbance chrysophyte assemblages in light of the shift to Synura species (Figs. 5 and 6). In Lagarde lake, the continued increase of S. echinulata towards the top of the core makes it appear that Lagarde lake is still acidifying. More likely, this reflects the shift to Synura-dominated assemblages that has been observed across much of Ontario (Paterson et al., 2001, 2004; S.S. Dixit et al., 2002). S. petersenii, an important contributor to these shifts in many lakes, also shows signs of a continued increase in relative abundance. In Blueberry lake, both $S$. echinulata and S. sphagnicola began decreasing in sediment dated from approximately the 1990 s, but this was coincident with increases in the relative abundance of $S$. petersenii.

Similarly, in recent studies of phytoplankton data from intensively-studied lakes in southcentral Ontario (Paterson et al., 2008), and paleoecological data from the southern Canadian Shield (Paterson et al., 2001, 2004), increases in the abundance of colonial chrysophytes (including Synura) have also been reported. In other regions, the timing of these increases is coeval with water chemistry changes associated with industrial activity since the mid 1900s, and physical changes in lakes associated with recent warming. Moreover, in a meta-analysis of paleolimnological data from more than 250 lakes across northeastern North America, Hyatt et al. (2010) hypothesized that the increases in colonial chrysophytes may be related to long-term declines in total phosphorus concentrations associated with catchment acidification and recent warming (Eimers et al., 2009). Clearly, further work will be required to determine the site-specific causes of increases in Synura taxa in the Wawa fume-kill area lakes.

\section{CONCLUSIONS}

In summary, the scaled-chrysophytes species compositions in the five study lakes from a fume-kill area near Wawa were altered markedly in response to a period of iron sintering from 1939 to 1998 . The most consistent re- sponse was an increase in acid- and metal-tolerant Synura echinulata in each lake's core. Similar to many previous acidification studies, the response of scaled-chrysophytes in the fume-kill lake sediment records predated the response of diatoms, substantiating the value of using both proxies in paleolimnological $\mathrm{pH}$ reconstructions. Following water quality improvements, the response of scaledchrysophytes was variable across the study lakes. In some lakes, recovery was interpreted from a decrease in the acid- and metal-tolerant species $S$. echinulata towards the top of the core. Two lakes appear to have shifted from a Mallomonas-dominated to a Synura-dominated species assemblage, implying that there may have been alterations to nutrient dynamics and/or thermal regimes of these lakes (Hyatt et al., 2010). Although $\mathrm{pH}$ and other water quality variables may have recovered in some systems, the chrysophyte assemblages present in the recent sediments are still markedly different from those thriving during predisturbance times.

\section{ACKNOWLEDGEMENTS}

The authors would like to thank Don A. Jackson and Keith M. Somers for their general observations and invaluable background information concerning the Wawa lakes. They are also grateful to Adam Jeziorski and Amy E. Tropea for their assistance in the field. This work was funded through a Natural Sciences and Engineering Research Council grant to John P. Smol.

\section{REFERENCES}

Appleby PG, Oldfield F, 1978. The calculation of lead-210 dates assuming a constant rate of supply of unsupported ${ }^{210} \mathrm{~Pb}$ to the sediment. Catena 5:1-8.

Asmund B, Kristiansen J, 1986. The genus Mallomonas (Chrysophyceae). A taxonomic survey based on the ultrastructure of silica scales and bristles. Opera Bot. 85:1-128.

Battarbee RW, Jones VJ, Flower RJ, Cameron NG, Bennion H, Carvalho L, Juggins S, 2001. Diatoms, p. 155-202. In: J.P. Smol, H.J.B. Birks and W.M. Last (eds.) Tracking environmental change using lake sediments. Volume 3: Terrestrial, algal, and siliceous indicators. Kluwer Academic Publishers.

Binford MW, 1990. Calculation and uncertainty analysis of ${ }^{210} \mathrm{~Pb}$ dates for PIRLA project lake sediment cores. J. Paleolimnol. 3:253-267.

Carignan R, 1985. Quantitative importance of alkalinity flux from the sediments of acid lakes. Nature 317:158-160.

Charles DF, 1990. Effects of acidic deposition on North American lakes: paleolimnological evidence from diatoms and chrysophytes. Philos. T. Roy. Soc. B 327:403-412.

Clarke KR, Warwick RM, 1994. Change in marine communities: an approach to statistical analysis and interpretation. Natural Environmental Resource Council, Bourne Press Limited.

Coker WB, Shilts WW, 1979. Lacustrine geochemistry around the north shore of Lake Superior: implications for evaluation of the effects of acid precipitation, paper 79-1C, p. 1-15. In: Current Research, Part C., Geological Survey of Canada, Ottawa. 
Cumming BF, Davey KA, Smol JP, Birks HJB, 1994. When did acid-sensitive Adirondack lakes (New York, USA) begin to acidify and are they still acidifying? Can. J. Fish. Aquat. Sci. 51:1550-1568.

Cumming BF, Smol JP, Birks HJB, 1992a. Scaled chrysophytes (Chrysophyceae and Synurophyceae) from Adirondack drainage lakes and their relationship to environmental variables. J. Phycol. 28:162-178.

Cumming BF, Smol JP, Kingston JC, Charles DF, Birks HJB, Camburn KE, Dixit SS, Uutala AJ, Selle AR, 1992b. How much acidification has occurred in Adirondack region lakes (New York, USA) lakes since pre-industrial times? Can. J. Fish. Aquat. Sci. 49:128-141.

Davis RB, Anderson DS, Dixit SS, Appleby PG, Schauffler M, 2006. Responses of two New Hampshire (USA) lakes to human impacts in recent centuries. J. Paleolimnol. 35:669697.

Dixit AS, Dixit SS, Smol JP, 1992a. Long-term trends in lake water $\mathrm{pH}$ and metal concentrations inferred from diatoms and chrysophytes in three lakes near Sudbury, Ontario. Can. J. Fish. Aquat. Sci. 49(S1):17-24.

Dixit AS, Dixit SS, Smol JP, 1992b. Algal microfossils provide high temporal resolution of environmental trends. Water Air Soil Poll. 62:75-87.

Dixit AS, Dixit SS, Smol JP, 1996. Long-term trends in limnological characteristics in the Aurora trout lakes, Sudbury, Canada. Hydrobiol. 335:171-181.

Dixit SS, Dixit AS, Smol JP, 1989a. Lake acidification recovery can be monitored using chrysophycean microfossils. Can. J. Fish. Aquat. Sci. 46:1309-1312.

Dixit SS, Dixit AS, Evans RD, 1989b. Paleolimnological evidence for trace-metal sensitivity in scaled chrysophytes. Environ. Sci. Technol. 23:110-115.

Dixit SS, Dixit AS, Smol JP, 1992. Assessment of changes in lake water chemistry in Sudbury area lakes since preindustrial time. Can. J. Fish. Aquat. Sci. 49(S1):8-16.

Dixit SS, Dixit AS, Smol JP, 1999. Lake sediment chrysophyte scales from the northeastern U.S.A. and their relationship to environmental variables. J. Phycol. 35:903-918.

Dixit SS, Dixit AS, Smol JP, 2002. Diatom and chrysophyte transfer functions and inferences of post-industrial acidification and recent recovery trends in Killarney lakes (Ontario, Canada). J. Paleolimnol. 27:79-96.

Eimers MC, Watmough SA, Paterson AM, Yao H, 2009. Longterm declines in phosphorus export from forested catchments in south central Ontario. Can. J. Fish. Aquat. Sci. 66:1682-1692.

Gibson KN, Smol JP, Ford J, 1987. Chrysophycean microfossils provide new insight into the recent history of a naturally acidic lake (Cone Pond, New Hampshire). Can. J. Fish. Aquat. Sci. 44:1584-1588.

Glew JR, 1988. A portable extruding device for close interval sectioning of unconsolidated core samples. J. Paleolimnol. $1: 235-239$

Glew JR, 1989. A new trigger mechanism for sediment samplers. J. Paleolimnol. 2:241-243.

Gordon AG, Gorham E, 1963. Ecological aspects of air pollution from an iron-sintering plant at Wawa, Ontario. Can. J. Bot. 41:1063-1078.

Greenaway CM, 2009. Diatoms community responses to water quality improvements in lakes recovering from acidification and metal-contamination near Wawa, Ontario, Canada: a paleolimnological perspective. M.Sc. thesis, Department of Biology, Queen's University, Kingston, ON, Canada.

Greenaway CM, Paterson AM, Keller W, Smol JP, 2012. Dramatic diatom species assemblage responses in lakes recovering from acidification and metal contamination near Wawa, Ontario, Canada: a paleolimnological perspective. Can. J. Fish. Aquat. Sci. 69:656-669.

Gunn JM, 1995. Restoration and recovery of an industrial region. Springer-Verlag Publishers.

Hartmann H, Steinberg C, 1986. Mallomonadacean (Chrysophyceae) scales: early biotic paleoindicators of lake acidification. Hydrobiol. 143:87-91.

Hyatt CV, Paterson AM, Cumming BF, Smol JP, 2010. Factors related to regional and temporal variation in the distribution of scaled chrysophytes in northeastern North America: evidence from lake sediments. Nova Hedwigia. 136:87-102.

Kling HJ, Kristiansen J, 1983. Scale-bearing Chrysophyceae (Mallomonadaceae) from central and northern Canada. Nor. J. Bot. 3:269-290.

Nicholls KH, 1982. Mallomonas species (Chrysophyceae) from Ontario, Canada, including descriptions of two new species. Nova Hedwigia 36:89-112.

Nicholls KH, Gerrath JF, 1985. The taxonomy of Synura (Chrysophyceae) in Ontario with special reference to taste and odour in water supplies. Can. J. Bot. 63:1482-1493.

Ontario Ministry of the Environment, 1999. Studies of the terrestrial environment in the Wawa area 1998-1999. Ontario Ministry of the Environment, Toronto, Ontario. Available from: http//www.archive.org/details/studiesofterrest00ontauoft [Accessed on: 25 September 2011].

Paterson AM, Cumming BF, Smol JP, Hall RI, 2001. Scaled chrysophytes as indicators of water quality changes since preindustrial times in the Muskoka-Haliburton region, Ontario, Canada. Can. J. Fish. Aquat. Sci. 58:2468-2481.

Paterson AM, Cumming BF, Dixit SS, Smol JP, 2002. The importance of model choice on $\mathrm{pH}$ inferences from scaled chrysophyte assemblages in North America. J. Paleolimnol. 27:379-391.

Paterson AM, Cumming BF, Smol JP, Hall RI, 2004. Marked recent increases of colonial scaled chrysophytes in boreal lakes: implications for the management of taste and odour events. Freshwat. Biol. 49:199-207.

Paterson AM, Winter JG, Nicholls KH, Clark BJ, Ramcharan CW, Yan ND, Somers KM, 2008. Long-term changes in phytoplankton composition in seven Canadian Shield lakes in response to multiple anthropogenic stressors. Can. J. Fish. Aquat. Sci. 65:846-661.

Rao DN, LeBlanc F, 1967. Influence of an iron-sintering plant on corticolous epiphytes in Wawa, Ontario. Bryologist 70:141-157.

Rowe J, 1999. Heart of a mountain, soul of a town: the story of Algoma Ore and the town of Wawa. Friesens Publisher, Altona, Canada.

Sage RP, 1993. Geology of Chabanel, Esquega, Lastheels and McMurray Townships, District of Algoma. Ontario Geological Survey, Open File Report 5586.

Sage RP, 1994. Geology of the Michipicoten greenstone belt. Ontario Geological Survey, Open File Report 5888. 
Sandgren CD, 1988. The ecology of chrysophyte flagellates: their growth and perennation strategies as freshwater phytoplankton, p. 9-104. In: C.D. Sandgren (ed.), Growth and reproductive strategies of freshwater phytoplankton. Cambridge University Press, Cambridge, UK.

Schelske CL, Peplow A, Brenner M, Spencer CN, 1994. Lowbackground gamma counting: applications for $210 \mathrm{~Pb}$ dating of sediments. J. Paleolimnol. 10:115-128.

Schiff SL, Anderson RF, 1986. Alkalinity production in epilimnetic sediments: acidic and non-acidic lakes. Water Air Soil Poll. 31:941-948.

Schindler DW, Turner MA, Stainton MP, Linsey GA, 1986. Natural sources of acid neutralizing capacity in low alkalinity lakes of the Precambrian Shield. Science 232:844-847.

Schindler DW, Curtis PJ, Parker BR, Stainton MP, 1996. Consequences of climate warming and lake acidification for UVB penetration in North American boreal lakes. Nature 379:705-708.

Siver PA, 1991. The biology of Mallomonas: Morphology, taxonomy and ecology. Kluwer Academic Publishers.

Siver PA, Hamer JS, Kling H, 1990. Separation of Mallomonas duerrschmidtiae sp. nov. from $M$. crassisquama and $M$. pseudocoronata: implications for paleolimnological research. J. Phycol. 26:728-740.

Smol JP, 1980. Fossil synuracean (Chrysophyceae) scales in lake sediments: a new group of paleoindicators. Can. J. Bot. 58:458-465.
Smol JP, 1988. Chrysophycean microfossils in paleolimnological studies. Palaeogeogr. Palaeocl. 62:287-297.

Smol JP, 1995. Application of chrysophytes to problems in paleoecology, p. 303-329. In: C.D. Sandgren, J.P. Smol and J. Kristiansen (eds.), Chrysophyte algae: Ecology, phylogeny and development. Cambridge University Press, Cambridge, UK.

Smol JP, Cumming BF, Dixit AS, Dixit SS, 1998. Tracking recovery patterns in acidified lakes: a paleolimnological perspective. Restor. Ecol. 6:318-326.

Smol JP, Dixit SS, 1990. Patterns of $\mathrm{pH}$ change inferred from chrysophyte microfossils in Adirondack and northern New England lakes. J. Paleolimnol. 4:31-41.

Somers KM, 1980. Alterations of lake fish communities in response to acid precipitation and heavy metal loading near Wawa, Ontario. M.Sc. thesis, University of Toronto, Ontario, Canada.

Somers KM, Harvey HH, 1984. Alteration of fish communities in lakes stressed by acid deposition and heavy metals near Wawa, Ontario. Can. J. Fish. Aquat. Sci. 41:20-29.

Takahashi E, 1978. Electron microscopical studies of the Synuraceae (Chrysophyceae) in Japan: Taxonomy and ecology. Tokai University Press, Tokyo, Japan.

Uutala AJ, Yan ND, Dixit AS, Dixit SS, Smol JP, 1994. Paleolimnological assessment of damage to fish communities in three acidic, Canadian Shield lakes. Fish. Res. 19:157-177. 